\title{
The Function and Meaning of Headdress (Blangkon and Udeng) Amid Community Social Changes
}

\author{
Nise Samudra Sasanti ${ }^{1}$ \\ Faculty of Language and Arts, Department of Japanese Language and Literature, Japanese \\ Language Education,Universitas Negeri Surabaya'Jl. Lidah Wetan, Lidah Wetan, Kec. \\ Lakarsantri, Surabaya, Jawa Timur, Indonesia ${ }^{1}$ \\ $\left\{\underline{\left.\text { nisesamudra@unesa.ac.id }{ }^{1}\right\}}\right.$
}

\begin{abstract}
The headdress, especially worn by men, is identical to the traditional Indonesian dress. Not only had the Javanese community, but most of Indonesia's customs also used headdress to complement traditional clothing. People in Central Java call it Blangkon while those in East Java call it Udeng. Based on their naming and shapes, the headdress has deeper functions and meanings. It can reflect the customs and culture of a region. The shape of the headdress from Yogyakarta, Solo, and East Java especially Surabaya and Madura are different. Yogyakarta has a spherical Mondolan on the back side while Surabaya has a unique form of Udeng, shaped like a triangle reaching high up. Special characteristics also have different meanings. This study focused on functions and also implicit and expressed meanings of the headdress wearer's community. This research used a qualitative descriptive method to obtain a description of the use of blangkon and udeng as well as their meanings. The data-collecting techniques are observation data collection, interviews, and documentation, while the dataanalysis technique is a qualitative data analysis technique. Results of the study showed that headdress is used for 1) protecting the head from the hot sun, 2) showing social status which is influenced by the type of fabric and its motives, and 3) showing very synchronous personalities. Blangkon has expressed and implicit meanings, namely a) the people of Surabaya and Madura are depicted as rude and outspoken, b) the people of Central Java Island are refined and polite personality in speech.
\end{abstract}

Keywords: Social Change; Function; Meaning; Headdress; Community; Blangkon; Udeng

\section{Introduction}

Headdress is a complement to the traditional clothes of a region. Generally, it has a designation based on the origin area of the headdress. The headdress is named Blangkon in Central Java and it is called as Udeng in East Java. It has different designations but it carries the same function and meaning. Blangkon and Udeng function as headdress. Some say that the head covering is an influence of Hindu and Islamic culture. Traders of Arab descentwore 
turban, a long cloth wrapped around the head, which inspired the Javanese to wear headbands.

Generally, the blankon is used as a complement for traditional Javanese traditional clothing, especially during Javanese traditional wedding ceremonies. Apart from being customary clothing complement, blangkon also serves to protect the head from the sun. In addition, blangkon is also worn to show the dignity and social level of the wearer (Pramudya

2012). According to Soegeng (Toekio n.d.), blangkon is a kind of hat in the form of iket or udeng which comes from the word 'blangko' which means printing blank. This is a name given to the types of tags that have been printed(Toekio n.d.). The value of everyday life can also be found in a blangkon. The value of life that reflects a beauty, perseverance, thoroughness, and patience.

Udeng is a headband worn by men in East Java since the past, the use of udeng in the past is a must because it is believed to drive out evil spirits(Udeng Jawa Timur 2016). Not only blangkon, udeng can also be a class differentiator in a society and as a complement to traditional ceremonies.

According to its shape, blangkon and udeng are divided into several styles. Each blangkon or udeng actually has its own style. There are also many types of blangkon in the community, but on this occasion, there are only four styles to be discussed.

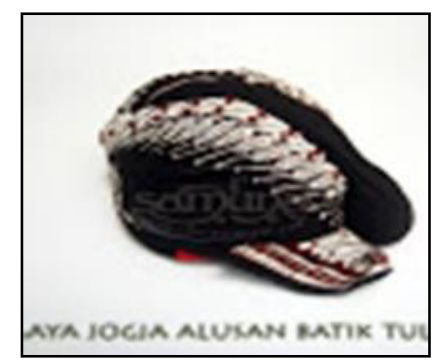

Figure 1. Yogyakarta Style Blangkon

The Jogja-style blangkon has a mondolan on the back. Mondolan is round like an ondeonde (Sundari 2017). Furthermore, Sundari said that mondolan is also closely related to the philosophy of the Javanese who are expected to be good at keeping secrets and are not easy to reveal disgrace, both themselves' or others'(Sundari 2017). They are smooth-talkers, gentle in behavior and careful as a manifestation of nobility. A wise person will be able to smile and laugh even though his heart is crying. He only thinks about how to do well to others, even though he himself becomes the victim. Javanese people are often dubbed by the term mbendhol mburi which means they always says they agree, but they also curse secretly behind others' back. 


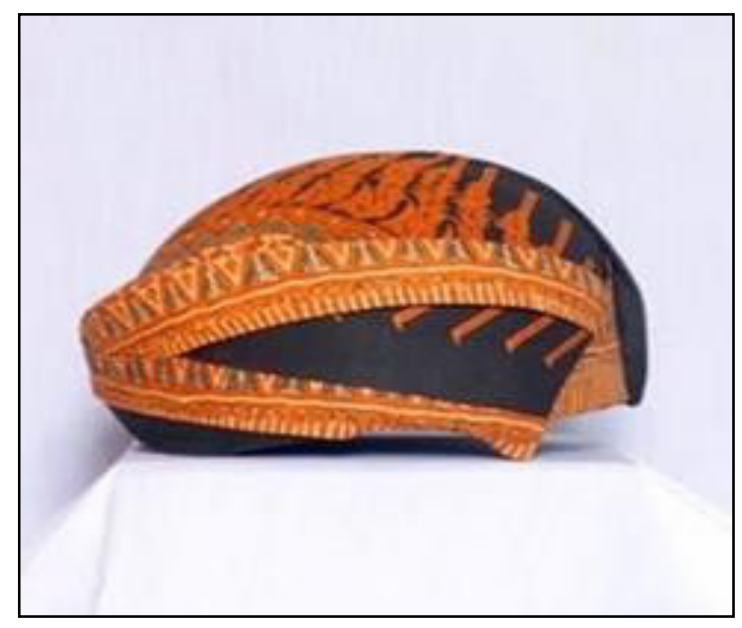

Figure 2. Surakarta Style Blangkon

The Solo-style blankon is different from Jogja-style blangkon. It still has mondholan but the flat one. The people of Solo have already known the term haircut because of the Dutch influence. They knew a coat called beskap which comes from the word beschaafd which means civilized or cultured. Due to Dutch influence, the people of Solo were first acquainted with shaving. They were even familiar with a coat called beskap, which originates from the word itself is beschaafd (cultured/civilized). The meaning of blangkon in this case is a symbol of a meeting between the jagad alit (microcosm) and the jagad gedhe (macrocosm). The blangkon has the role of jagad gedhe, while the head indicates the jagad alit. Blangkon symbolizes the power of God, the head as the caliph. (Sundari 2017)

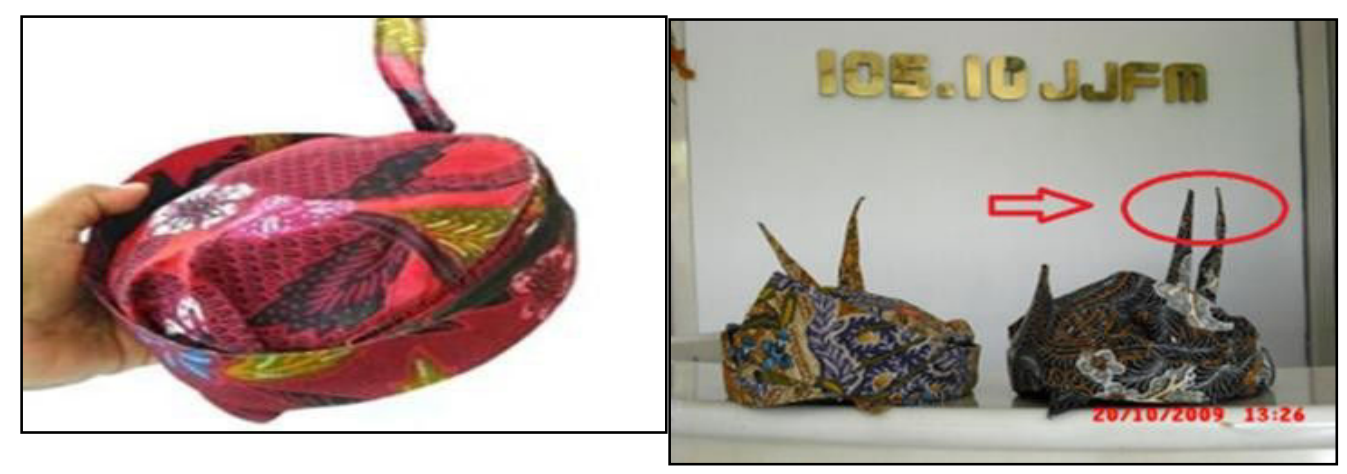

Figure 3. East Java Style (Surabaya \& Madura) 
Certain groups consider the East Javanese to have characteristics of being rude and outspoken. If there is something stuck in the heart, East Javanese prefer to express their feelings. This outspoken nature reflects the courage and high enthusiasm of the people of East Java.

This study aims to examine the meaning behind a headdress commonly used in society. The meaning explored is not only the meaning of usage, but also the meaning of the life it contains. Apparently, blangkon or udeng also indicates the nature and position of each wearer. The wearer in question is a wearer who comes from the area, a wearer who can be said to be the originators who then participates in preserving.

\section{Method}

This research used a descriptive qualitative research method. This is based on the research objective, namely to obtain a description of the use of blangkon and udeng and the meaning attached in the personality of each wearer.

This research is humanities research. This research is based on truth on human experience and relations thus it can approach the truth. In addition, this research on blangkon and udeng intends to show that each individual blangkon and udeng wearer is unique and different. In fact, humans are creatures that have many unique and fun differences.

\section{Result and Discussion}

\subsection{Functions and Meanings of Headdress (Blangkon/Udeng)}

Udeng becomes a social characteristic of a person, depending on the material, color and shape of the clothes. The Madura-style blangkon has the same shape as Surabaya-style blangkon. The distinctive feature of Surabaya-style and Madura-style udeng is the towering triangle shape. Both have the same features and shapes. Based on this, the people of Surabaya and Madura can also be said to have the same meaning, namely the meaning of enthusiasm which also influences the same characteristics owned by the community, considering that Surabaya and Madura are adjacent areas.

Mondolan which is owned by Jogja-style and Solo-style blangkon also influences its function and meaning. The location of the area which is not far away also influences each other's clothing attributes and the meaning behind them. While the Surabaya-style and Madura-style blangkon depict courage and burning passion, the Jogja-style and Solo-style blangkon have a subtle and gentle meaning. This also affects the personality of the wearer.

\subsection{Headdress as a Reflection of the Personality of the Wearer}

Studies on headdress are rarely exposed to the surface so that many people do not really know the meaning of blangkon other than functioning only as a head covering. Despite the fact that the blangkon does not only function as a head covering, behind it all, it also contains the social status of the wearer as seen from the fabric, as well as the motif of the blangkon.

It is said that the headdress reflects the personality of the wearer. Its various styles have explicit and implied meanings. The explicit meaning is what is written or reviewed by experts. The implied meaning is reflected in the wearer's personality. The people of Central Java have a subtle personality in their speech. However, they keep something that can cause problems 
later in the future. The people of East Java have their personality reflected with a harsh and blunt accent. They express what they feel directly to the person concerned but the problem is resolved immediately.

\section{Conclusion}

Based on the things that have been stated previously, it can be concluded that there are 3 functions of blangkon and udeng, namely protecting the head from the hot sun, showing social status which is influenced by the type of fabric and its motives, and showing very synchronous personalities.

The meaning of blangkon in this research is classified into two. The first part is the classification carried out in the eastern island of Java, namely Surabaya and Madura. The people of Surabaya and Madura are depicted as rude and outspoken, people who prefer to express their feelings rather than bury them. In relation for this, for the record, the people of eastern Java Island tend to give up an incident after all their grievances have been well conveyed.

The second classification is shown in the people of Central Java Island, namely Jogja and Solo. Both areas have blangkon which shows a refined and polite personality in speech. This is inversely proportional to Surabaya and Madura. By always keeping feelings and secrets, the people of Yogyakarta and Solo prefer to keep things hidden rather than express them. They have the same passion but with more careful delivery of feelings and tend to be closed. That is the description of the four types of blangkon with the two classifications of functions and the meanings that cover.

\section{References}

[1] Arikunto, Suharsimi. 1990. Prosedur Penelitian. Jakarta: Rinclce Cipto.

[2] Direktorat Jenderal Kebudayaan, ed. 1990. Pakaian Adat Tradisional Daerah Istimewa Yogyakarta. Jakarta: Departemen Pendidikan dan Kebudayaan.

[3] Gus. 2016. "'Mondolan' Blangkon Jogja Dan Solo Beda, Ini Penjelasannya." KrJogja.com. https://www.krjogja.com/berita-lokal/diy/yogyakarta/mondolanblangkon-jogja-dan-solo- beda-ini-penjelasannya/ (November 8, 2020).

[4] "Kamus Besar Bahasa Indonesia Daring." 2016. KBBI. https://kbbi.kemdikbud.go.id/Beranda/TentangKami.

[5] Koentjaraningrat. 1983. Metode-Metode Penelitian Masyarakat. Jakarta: Gramedia. Maryaeni. 2005. Metode Penelitian Kebudayaan. Jakarta: Bumi Aksara.

[6] Purnomo, Husaini Usman. 2008. Metodologi Penelitian Sosial. Jakarta: Bumi Aksara.

[7] Pramudya, Ayu (Unika Soegijaprana). 2012. "Landasan Teori Dan Program Kawasan Industri Blangkon Berbasis Rumah Penekanan Desain Penerapan Kearifan Lokan Pada Desan Kawasan Industri Blangkon Yang Berbasis Pada Rumah Tangga." Unika Soegijaprana.

[8] Sundari, Dewi. 2017. "Makna Blangkon Bagi Orang Jawa." Kompasiana:Beyong Blogging.

https://www.kompasiana.com/dewisundari/591bec387fafbdc01ebc102e/makna- 
blangkon-bagi- orang-jawa?page=all\#sectionall (November 10, 2020).

[9] Suryabrata, Sumadi. 2018. Metode Penelitian. 28th ed. Jakarta: Raja Grafindo.

[10] Tiana, Ayu Lukita. 2013. "Analisis Makna Blangkon Pola Yogyakarta.” Journal of Pesagi: Jurnal Pendidikan dan Penelitian Sejarah 1. http://jurnal.fkip.unila.ac.id/index.php/PES/article/view/3064.

[11] Toekio, Soegeng. Tutup Kepala Tradisional Jawa. Jakarta: Departemen Pendidikan dan Kebudayaan. "Udeng: Fungsi, Status, Dan Makna Filosofis." 2016. Julajuli.com.

[12] https://cityguide.suarasurabaya.net/read/2016/07/20/243/Udeng Fungsi Status Makna_Fil

osofis\#: : :text=Makna\%2520Filosofis\%2520Udeng\&text=Maknanya\%252C\%2520 agar $\% 2520$ seseo rang\% 025 20memiliki\%2520kecakapan,sebagai\%2520simbol\%2520trinetra\%2520atau\%2520 tritungga (November 8, 2020).

[13] "Udeng Jawa Timur." 2016. https://www.facebook.com/318735844917313/posts/udeng-jawa- timurudengtimuran-adalah- ikat-kepala-yang-dipakai-kaum-pria-jawa-tim/333861633404734/ (November 10, 2020).

[14] WB, Thomas. 2006. Upacara Perkawinan Adat Jawa. Jakarta: Pustaka Sinar Harapan. 